\title{
Sindromul Potter, o entitate rară cu risc de recurență la femeile cu malformații renale - prezentare de caz şi date din literatură
}

\author{
George Rolea', Claudiu Mărginean', Vlăduț Ştefan Săsăran², Cristian Dan Mărginean², \\ Lorena Elena Meliț ${ }^{3}$ \\ ${ }^{1}$ Clinica Obstetrică şi Ginecologie I, Târgu Mureş, România \\ Universitatea de Medicină şi Farmacie, Târgu Mureş, România \\ ${ }^{3}$ Clinica Pediatrie I, Tâgu Mureş, România
}

\begin{abstract}
REZUMAT
Sindromul Potter reprezintă o asociere dintre un fenotip specific şi hipoplazie pulmonară ca rezultat al oligohidramniosului, care poate surveni în anumite condiții patologice. Astfel, sindromul Potter de tip I sau boala renală polichistică autozomal recesivă este o patologie cu incidență relativ rară şi prognostic infaust atunci când este diagnosticată în timpul vieții intrauterine. Prezentăm cazul unei femei în vârstă de 24 de ani, internată în clinica noastră prezentând o sarcină în evoluție, 22/23 săptămâni gestaționale, la care ecografia fetală de rutină a evidențiat oligohidramnios, displazie renală polichistică şi hipoplazie pulmonară. Antecedentele personale patologice au relevat faptul că, în urmă cu 2 ani, pacienta a suferit un avort terapeutic la vârsta de 16 săptămâni gestaționale pentru aceleaşi motive. Ecografia maternă a arătat agenezie renală maternă unilaterală. Din cauza faptului că malformația evidențiată era incompatibilă cu viața, s-a indus avortul terapeutic. Particularitatea cazului constă în diagnosticarea sindromului Potter la două sarcini consecutive la o femeie în vârstă de 24 de ani, fără antecedente heredocolaterale cunoscute, însă care este diagnosticată cu agenezie renală unilaterală.

Cuvinte cheie: sindrom Potter, boală renală polichistică autozomal recesivă, oligohidramnios
\end{abstract}

\begin{abstract}
Abrevieri:
Hb: hemoglobină

Leu: leucocite

Neu: neutrofile

\section{INTRODUCERE}

BRPAR: boală renală polichistică autozomal recesivă

Anomaliile de dezvoltare renală reprezintă o categorie de malformații congenitale foarte frecventă, aproximativ $20-30 \%$ din totalitatea defectelor structurale de dezvoltare, ducând în multe cazuri la ultimul stadiu de boală renală cronică (1).

Boala renală polichistică autozomal recesivă (BRPAR) este o patologie relativ rară, prezentând o incidență de aproximativ 1 la 20.000 de nou-născuți vii, caracterizată prin alungirea anormală a tubilor colectori care se transformă în multiple chiste renale mici (2). Transmiterea acestei patologii se realizează după modelul autozomal recesiv, iar cea mai frecventă genă care a fost identificată a fi implicată în etiologia ei este PKHD1 (3). Cu toate acestea, dat fiind faptul că o mică parte din aceşti copii supraviețuiesc în perioada neonatală fără a prezenta simptomatologie severă, s-a emis ipoteza că ar exista şi mutații la nivelul altor gene care ar putea duce la BRPAR (4). Dilataţia chistică a tubilor apare predominant în medulară din cauza lipsei tubilor în cortex, putând fi de diferite dimensiuni (2). Diagnosticul intrauterin este stabilit în majoritatea cazurilor în trimestrul II de sarcină, iar cel mai frecvent aspect ultrasonografic este de rinichi de dimensiuni foarte crescute, hiperecogeni, fără dife- 
rențiere corticomedulară. Acest aspect se poate asocia cu hipoplazie pulmonară şi oligohidramnios, caz în care prognosticul este extrem de slab, ducând în majoritatea cazurilor la moarte fetală sau neonatală (2). Sinonimele BRPAR sunt boală renală polichistică infantilă sau Potter tip I (2).

Sindromul Potter, altfel denumit secvenţa Potter sau secvență oligohidramnios, presupune asocierea dintre anumite trăsături fenotipice şi hipoplazie pulmonară ca rezultat direct al oligohidramniosului şi compresiei în timpul vieții intrauterine (5). Sindromul a fost denumit după patologul Edith Potter, care a descris pentru prima dată, în anul 1946, trăsăturile faciale caracteristice asociate ageneziei renale bilaterale, însă există, de asemenea, și alte cauze care pot genera oligohidramnios, precum: uropatia obstructivă, boala polichistică renală, hipoplazia renală şi ruptura prematură de membrane (5). Astfel, sindromul Potter clasic presupune agenezie renală bilaterală, însă mai există 4 subcategorii de sindrom Potter care apar ca rezultat al altor entități clinice, astfel: sindromul Potter tip I sau BRPAR, sindromul Potter tip II sau displazie renală, sindromul Potter tip III sau boală renală polichistică autozomal dominantă şi sindromul Potter tip IV sau uropatie obstructivă (fie la nivelul rinichiului, fie la nivelul ureterului) (6).

Prognosticul pacienţilor cu sindrom Potter tip I depinde în cea mai mare parte de momentul diagnosticului, astfel prognosticul este cu atât mai sever cu cât microchistele renale apar mai repede, iar în cazul în care aceştia supraviețuiesc perioadei neonatale, prognosticul se îmbunătăţeşte considerabil (2).

\section{PREZENTARE DE CAZ}

Prezentăm cazul unei paciente în vârstă de 24 ani, cu o sarcină în evoluție, având vârsta gestațională de 23/23 săptămâni, al cărei făt a fost depistat cu malformație renală incompatibilă cu viața la ecografia abdominală de rutină, astfel că s-a internat în clinica noastră în vederea inducerii unui avort terapeutic. Antecedentele heredocolaterale nu au evidențiat elemente patologice semnificative, însă cele personale patologice au relevat faptul că pacienta a mai prezentat o sarcină în urmă cu aproximativ 2 ani pentru care a beneficiat de asemenea de avort terapeutic la 16 săptămâni gestaționale, fătul fiind diagnosticat cu sindrom Potter intrauterin.

Examenul clinic general precum şi cel local efectuat în momentul internării au fost în limite normale. Analizele de laborator au fost relativ normale, cu modificări minore, şi anume: anemie uşoară (Hb 11,3 g/dL), leucocitoză minimă asocia-

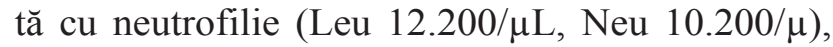
însă markerii inflamatorii au fost în limite normale. Am evaluat de asemenea funcția hepatică maternă şi cea renală, singurul element patologic identificat fiind o valoare a ureei uşor crescută (uree 44,62 $\mathrm{mg} / \mathrm{dL}$ ), însă valoarea creatininei a fost în limite normale.

Ecografia fetală a evidențiat următoare elemente: biometria fetală corespunzătoare unei vârste gestaționale de 22/23 săptămâni gestaţionale, făt viu în prezentație pelviană decompletă, modul feselor, lichid amniotic absent prin lipsă de producere, ambii rinichi cu displazie polichistică, toracele fetal deformat, cu suprafaţa cardiacă $>50 \%$ şi hipoplazie pulmonară evidentă, stabilind astfel diagnosticul de sindrom Potter (Fig. 1, 2, 3, 4).

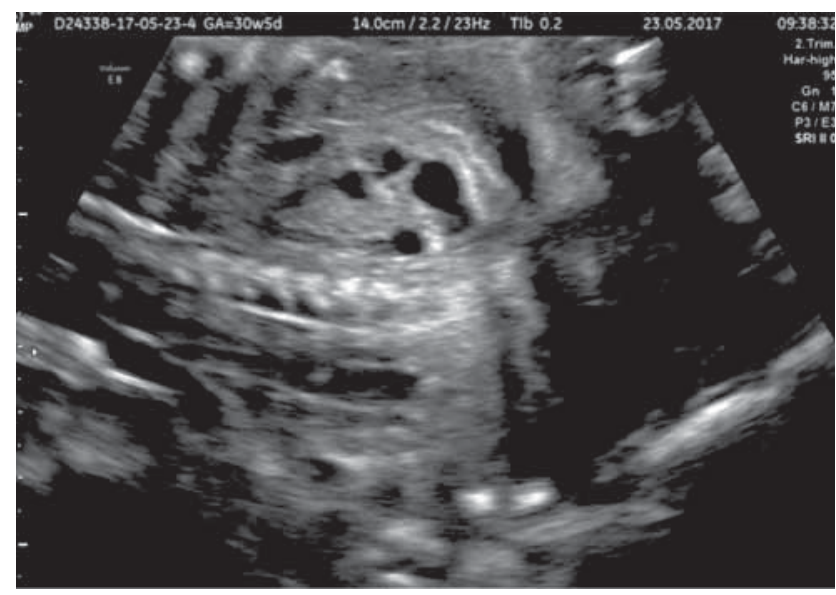

FIGURA 1. Rinichiul drept fetal (secțiune sagitală)

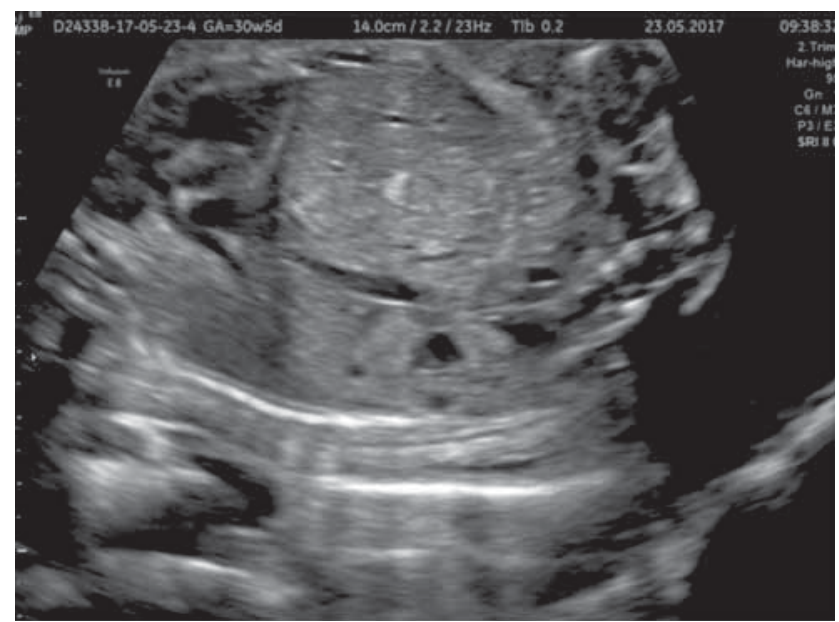

FIGURA 2. Rinichiul stâng fetal (secțiune sagitală)

Am evaluat de asemenea rinichii materni din punct de vedere ultrasonografic şi am identificat rinichi unic matern cu dilatație pielocaliceală moderată, însă cu funcție normală. Pe baza acestui fapt şi a recurenței sindromului Potter am ridicat suspiciunea unei mutații genetice ereditare, urmând ca pacienta să beneficieze de consiliere genetică. 


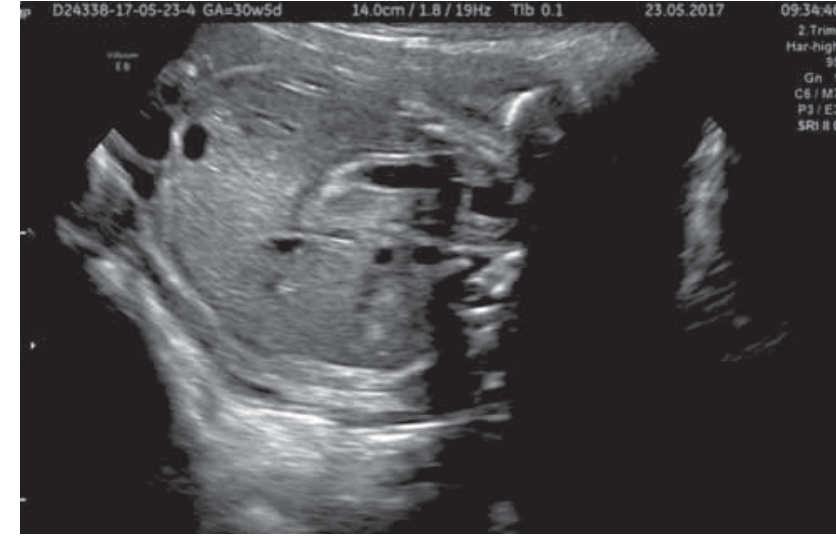

FIGURA 3. Secțiune transversală lombar fetal cu rinichii polichistici

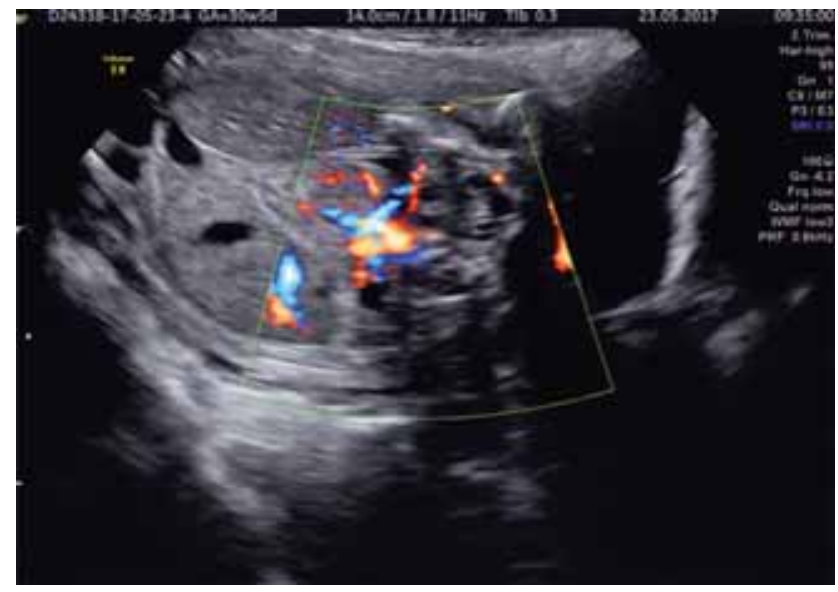

FIGURA 4. Arterele şi venele renale în secțiunea transversală fetală

Din cauza faptului că sindromul Potter grupează mai multe malformații severe, fiind incompatibil cu viaţa, am decis să inducem avort terapeutic.

Particularitatea cazului constă în diagnosticarea sindromului Potter la două sarcini consecutive la o femeie în vârstă de 24 de ani, fără antecedente heredocolaterale cunoscute, însă care este diagnosticată cu agenezie renală unilaterală.

\section{DISCUȚII}

Sindromul Potter este o patologie relativ rar întâlnită, a cărei incidență variază între 1:2.000 şi 1:5.000 cazuri (7), fiind rezultatul direct al oligohidramniosului, care poate apărea în diverse condiții patologice. Acest sindrom apare mai frecvent la sexul masculin (8). Dezvoltarea renală corespunzătoare este esențială pentru formarea lichidului amniotic, astfel că orice malformație renală care duce la imposibilitatea de formare sau eliminare a urinei va duce la oligohidramnios sau chiar anhidramnios. De exemplu, în cazul sindromului Potter clasic, şi anume cel asociat ageneziei renale bilaterale, cea mai gravă formă de sindrom Potter, metanefrosul nu va duce la dezvoltarea rinichilor (9). Oligohidramniosul cauzează restricţii de mobilitate şi creştere ducând la diverse diformități fizice, astfel că fenotipul caracteristic Potter poate fi asociat oricărei malformații urogenitale care este responsabilă pentru imposibilitatea de micționare intrauterină a fătului $(10,11)$. Printre anomaliile fenotipice clasice sindromului Potter pot fi întâlnite: hipoplazia mandibulară, contractura sau hipoplazia membrelor inferioare, disgenezia renală bilaterală, hipoplazie pulmonară etc. (12-14).

După vârsta de 16 săptămâni gestaționale cantitatea de lichid amniotic este direct dependentă de producția de urină fetală, care la rândul ei este esențială atât pentru dezvoltarea pulmonară prin furnizarea unei presiuni hidrodinamice necesare expansionării alveolare cât şi pentru maturarea plămânilor prin furnizarea prolinei, un aminoacid necesar acestui proces (12). Astfel că, în lipsa unei produceri adecvate de urină fetală, va apărea hipoplazia pulmonară. Similar, în cazul nostru, fătul prezenta, de asemenea, hipoplazie pulmonară. $\mathrm{Cu}$ toate că nu există metode de prevenție a acestei patologii, se recomandă efectuarea unei ecografii de screening pentru oligohidramnios şi malformații urogenitale între 16 şi 18 săptămâni gestaționale (15). Există de asemenea studii care susțin că ecografia morfologică pentru depistarea anomaliilor fetale este esenţială între 20 şi 22 săptămâni gestaționale (16).

Riscul de recurență al sindromului Potter este între 3 şi 6\% (8), fapt care susține importanța majoră a consilierii genetice în cazul gravidelor al căror făt este diagnosticat cu acest sindrom. Similar, în cazul prezentat mai sus, pacienta a prezentat două sarcini consecutive cu avort terapetic din cauza diagnosticului intrauterin de sindrom Potter. Important de menționat este faptul că, efectuând ecografie maternă, am observat că pacienta prezintă agenezie renală unilaterală, ridicând suspiciunea unei condiții genetice ereditare. Implicarea medicului specialist genetician în managementul acestor cazuri în vederea acordării unui sfat genetic adecvat cuplului prezintă o importanță majoră (16). Riscul de recurență este mult mai mare în cazul căsătoriilor cosangvine, fiind descrise cazuri de sindrom Potter recurent încă din secolul XX în cazul cosangvinității (17). În cazul pacientei noastre, nici una dintre sarcini nu a provenit din cosangvinitate.

$\mathrm{Cu}$ toate că sindromul Potter tip I sau BRPAR prezintă rată mare de mortalitate în prima lună de viaţă, necunoscându-se deocamdată nici o metodă profilactică sau terapeutică eficientă în afara transplantului renal, tehnologiile moleculare noi alături 
de metodele genetice clasice încearcă să identifice metode terapeutice țintite şi individualizate în acest scop.

\section{CONCLUZII}

Sindromul Potter este o patologie rară, cu risc de recurență, care reprezintă asocierea dintre un aspect caracteristic specific, diferite malformații re- nale, şi hipoplazie pulmonară ca rezultat direct al oligohidramniosului. Prognosticul este cu atât mai slab cu cât complicațiile apar mai precoce. În cazul diagnosticului intrauterin, în majoritatea cazurilor avortul terapeutic este metoda de elecție din cauza incompatibilității cu viața. Consilierea genetică este esentială în managementul adecvat al acestor cazuri. 